\title{
Teoria da Complexidade e as múltiplas abordagens para compreender a realidade social
}

The complexity theory and the multiple approaches to understanding the social reality

\author{
Luis Miguel Luzio dos Santos* \\ Edna Marta Pelosi** \\ Bernardo Carlos Spaulonci Chiachia Matos de Oliveira***
}

\begin{abstract}
Resumo:
Este ensaio é produto de uma reflexão sobre as múltiplas abordagens, que se contrapõe ao reducionismo e ao determinismo positivista hegemônico. Propõe-se a auxiliar na compreensão de como a Teoria da Complexidade apresenta-se como um modelo epistêmico mais frutífero para as ciências sociais à medida que apresenta uma visão mais complexa e ampliada da realidade. Parte-se, no entanto, num primeiro momento, da premissa de que a teoria geral dos sistemas, antes mesmo que o pensamento complexo, propõe-se a romper com o reducionismo, o mecanicismo e o determinismo clássico, mas falha justamente onde o primeiro é mais avassalador para a prática sócia I- na capacidade que este demonstrou durante longos anos de manter a regulação e a ordem vigente. Contudo, sem intencionar apresentar a Teoria da Complexidade como uma alternativa definitiva ao pensamento ortodoxo, faz-se um paralelo entre esta e a dialética marxista, com a qual, ao mesmo tempo em que parece dialogar, diverge num aspecto fundamental - a forma de conceber a mudança social - e a partir disto adentra-se na discussão sobre seu possível relativismo.
\end{abstract}

Palavras-Chave: Paradigma positivista. Teoria geral dos sistemas. Teoria da complexidade.

\section{Abstract:}

* Doutor em Ciências Sociais pela Pontifícia Universidade Católica de São Paulo - PUC/SP; Mestre em Administração pela Universidade Estadual de Londrina - UEL; Graduado em Economia e Administração, ambos pela Universidade Estadual de Londrina-UEL. Atualmente é Professor Adjunto do Departamento de Administração da Universidade Estadual de Londrina - UEL. Atua principalmente nos seguintes temas: Socioeconomia, Economia Solidária, Políticas Públicas, Terceiro Setor e solidariedade. Integrante do Projeto Rede de Apoio à Comercialização de Produtos e Serviços de Socioeconomia Solidária (PROSOL), financiado pelo programa "Universidade Sem Fronteiras": Extensão Tecnológica Empresarial da Fundação Araucária. Organizador do livro Economia Solidária em Londrina: aspectos conceituais e a experiência institucional. E-mail: Imig@uol.com.br

** Graduada em Adminsitração pela Universidade Estadual do Oeste do Paraná - Mestranda de Administração do PPGA-UEL. Atualmente é servidora da Universidade Tecnológica Federal do Paraná, onde ocupa o cargo de Administradora. E-mail: ednapelosi@gmail.com

*** Graduado em Administração pela Universidade Estadual de Londrina (2007); mestre em Administração (2012) (Programa de Pós-Graduação em Administração - PPGA-UEL), bolsista CAPES. E-mail: oliveira.bernardo@gmail.com 
This essay is a product of a reflection about the multiple approaches that opposes the reductionism and determinism hegemonic positivist. It is proposed to assist in the understanding how the Complexity Theory is presented as an epistemic model more fruitful to social sciences as it presents as more complex and extended view of the reality. It begins, however, at first, understanding that either general systems theory even before the complex thought it is proposed to break away from reductionism, mechanism, and classical determinism, but fails precisely where the first is more devastating to the social practice as it has demonstrated, for many years, the ability to maintain the existing order and regulation. However, without intending to introduce the Complexity Theory as a ultimate alternative to orthodox thinking, it is shown as a parallel between this and the Marxist dialectic, in which, while it seems to talk, and it differs in one fundamental aspect- the way of conceiving social change - hence enters into the discussion about its own possible relativism.

Keywords: Positivist paradigm. The general systems theory. The complexity theory.

\section{Introdução}

Para Thomas Kuhn (2005), o termo paradigma (do grego parádeigma: modelo, padrão, exemplo) é a visão de mundo que assegura a uma comunidade científica suas abordagens de investigação científica. São, portanto, realizações científicas universalmente reconhecidas que, durante certo período de tempo, fornecem modelos de problemas e soluções para uma comunidade de praticantes da ciência. Neste sentido, pesquisadores que compartilham do mesmo paradigma foram submetidos à mesma iniciação profissional e educacional similares, absorvendo a mesma literatura técnica e absorvendo delas as mesmas lições.

Segundo Serva, Dias e Aperstedt (2010), as ideias de Kuhn são especialmente importantes, porque permitem a compreensão das forças impulsionadoras e restritivas de novas teorias e ideias. Ao questionar o enfoque tradicional do progresso científico, este autor revela que a ciência está em constante estado de evolução, que ocorre de forma descontínua quando um paradigma é substituído por outro. A revolução científica ocorre quando o paradigma instaurado se vê total ou parcialmente superado por outro que desponta como um veículo mais apropriado para a teoria e a prática científicas, ou seja, trata-se de uma transformação dos princípios organizadores do conhecimento.

Nesse sentido, o paradigma funcionalista que representou a hegemonia absoluta nos estudos sociais e organizacionais até meados do século passado (SERVA; DIAS; 
APERSTEDT, 2010), dada a sua capacidade de fazer predições, estabelecer relações lineares de causa e efeito e, principalmente, de parecer exercer controle sobre as questões sociais, apresenta sinais de desgaste. Isso porque, ao transpor os modelos da ciência natural para a esfera social, excluiu desta análise dimensões humanas e subjetivas que não podiam ter sido renegadas, criando sérios obstáculos à compreensão das mudanças que estão hoje ocorrendo no mundo, fruto de sua própria racionalidade. Como asseveram Morin e Le Moigne (2000), a crise de responsabilidade e de consciência pela qual passa o racionalismo mecanicista postula a reintrodução do sujeito, de um sujeito que reflete sobre si mesmo, discute sobre ele mesmo, e contesta a própria ação.

Assim, reconhecendo a possibilidade de uma crise que se assenta principalmente nas características determinísticas e reducionistas do racionalismo científico, este ensaio perpassa por duas propostas que apontam para uma epistemologia mais ampliada da realidade: a teoria geral dos sistemas e a teoria da complexidade. A teoria geral dos sistemas por meio do conceito de sistemas abertos apresenta uma análise mais complexa da realidade social e aponta para uma reorientação da visão do observador para a diversidade, as inter-relações e os mecanismos de adaptação que ocorrem no sistema e entre ele e o ambiente (MORIN, 2005a). Contudo, segundo o entendimento neste ensaio, a TGS não se constitui uma evolução muito profícua, já que, ao buscar o equilíbrio constante, não consegue ver o conflito como potencial de transformação e, portanto, não consegue romper com os preceitos epistemológicos e teóricos vigentes.

No que se refere à complexidade, busca-se delinear como este paradigma reconhece a autonomia, a independência e o indeterminismo da parte perante o todo e, portanto, do sujeito perante a sociedade. Para possibilitar esta compreensão, recorre-se à reconceituação que Edgar Morin (2005a) apresenta em Ciência com Consciência acerca da teoria sistêmica. Desse feito, reconhece-se na complexidade a possibilidade de uma evolução metodológica no que se refere aos princípios deterministas cunhados pelo pensamento dominante.

Contudo, não intencionando colocar esta alternativa como perfeita ou definitiva, abre-se uma discussão sobre a forma como este paradigma concebe a mudança social, que, diferentemente da dialética (com a qual parece dialogar), não pressupõe a superação de um modelo de sociabilidade por outro, seja em termos econômicos ou 
outro qualquer. Discute-se, então, sobre o que pode parecer um possível relativismo por parte desta abordagem.

\section{O racionalismo científico}

O racionalismo científico que fundamenta a ciência moderna emergiu pela superação do paradigma escolástico predominante ao final da Idade Média, época em que os preceitos filosóficos Aristotélicos eram disseminados pelo clero, que buscava uma conciliação entre razão e fé, e, portanto, subordinava todo o conhecimento ao dogmatismo cristão. O Renascentismo e, posteriormente, o lluminismo são considerados pela história, o resgate da razão até então oprimida pelo obscurantismo do paradigma escolástico.

Entre os pioneiros dessa revolução científica destacam-se Nicolau Copérnico, que formulou a concepção heliocêntrica do universo; Galileu Galilei, considerado o fundador da física moderna, tendo comprovado, por meio do uso do telescópio, a teoria de Copérnico de que a terra gira em torno do sol; e Francis Bacon, criador do método empírico e propositor da metodologia indutiva. De Francis Bacon também deriva a ideia de que o bem-estar do homem depende do controle científico obtido por ele sobre a natureza. O homem, ministro e intérprete da natureza, faz e entende tanto quanto constata, pela observação dos fatos e pelo trabalho da mente, sobre a ordem da natureza; não sabe nem pode mais (BACON; CIVITA, 1999 ).

Contudo, é a René Descartes (1596-1650) e a Isaac Newton (1642-1727) que se atribui as maiores honras pela formulação da ciência moderna, ou ciência positivista como passou a ser chamada depois destes pensadores (BAUER, 2009). A visão de mundo que se disseminou depois desta época é denominada paradigma positivista ou, em reverência aos seus dois maiores artífices, "paradigma cartesiano-newtoniano".

Considerado o pai do racionalismo moderno, Descartes postulou serem as leis do pensamento regidas pelas leis da matéria. Consolidou as metodologias analítica (que representa o processo lógico de decomposição do objeto em seus componentes básicos) e dedutiva (que do geral apreende o particular, com base num rigoroso uso da matemática), também foi o principal mentor do princípio da causalidade, pelo qual os efeitos decorrem necessariamente das causas. Na busca de uma matemática universal, 
capaz de unificar os díspares campos do conhecimento, argumentava pela progressão de termos superiores por meio da informação dos anteriores, como se tudo pudesse ser derivado de causas primeiras (BAETA NEVES; NEVES, 2006).

Descartes foi também o autor do célebre postulado "Penso, logo existo", que levou à cristalização dos dualismos matéria-espírito e corpo-alma nas ciências e na filosofia, como bem ressalta Bauer (2009). A este respeito, Andery et al. (2007) explicam que, ao distinguir corpo e alma, Descartes atribui um valor diferente para cada um deles. O corpo humano identifica-se com os demais corpos do universo: é extenso, movimenta-se e pode ser explicado mecanicamente. Já a alma é a essência do ser humano e, diferentemente dos outros corpos, é inextensa e indivisível. No entanto, à alma cabe pensar, o que envolve entendimento (responsável pelo conhecimento) e vontade (à qual estão ligados o desejar, o negar, o duvidar). Cabe então à alma, a principal função na produção de conhecimento: desvendar o que as coisas são. Todavia, para Descartes isto só será possível por meio da razão, único elemento que, pelo método cartesiano, é capaz de chegar a leis ou princípios gerais acerca das coisas.

Assim, toda a natureza, poderia ser dividida em dois domínios exclusivos - o da mente (res cogitans) e o da matéria (res extensa) o que iria resultar no progressivo afastamento entre as ciências humanas, concentradas na "coisa pensante", e as naturais, voltadas à "coisa extensa" (BAUER, 2009, p. 23).

Isaac Newton, propositor de uma mecânica racional, postulou ser possível demonstrar, por meio das forças dos movimentos, todos os demais fenômenos da natureza. Newton também trouxe para seu modelo de universo a noção de espaço tridimensional da geometria euclidiana, da qual deriva as noções de espaço e tempo absolutos. O universo é ordenado e harmônico, existe uma ideia de totalidade que pode, após Newton, ser descrita por leis elegantes e simples (BAETA NEVES; NEVES, 2006, p. 184). Segundo a mecânica newtoniana, o mundo da matéria é uma máquina cujas operações podem se determinar exatamente por meio de leis físicas e matemáticas, um mundo estático e eterno a flutuar num espaço vazio, um mundo onde o racionalismo cartesiano se torna cognoscível por meio da decomposição das partes.

Assim, o que se configurou após estas ideias e empreendimentos foi uma visão de mundo sustentada em premissas tais como a ordem das coisas, a legislação universal, a 
sistematização do real, o absoluto, o determinismo mecanicista, a dualidade sujeitoobjeto, o rigor metodológico, a razão e a máquina. A concepção metafórica do universo como uma máquina leva à crença de que ele pode ser regido por leis perfeitas e imutáveis. Esta compreensão de mundo vai exercer influências em outros campos do saber, principalmente em decorrência das conquistas da revolução científica que se finalizam no século XVIII, reforçando a ideia de que a ordem e a estabilidade originárias deste pensamento são a precondição para a transformação tecnológica do mundo. A partir daí estão criadas as condições para a emergência das ciências sociais no século XIX (SANTOS, 2002).

Dessa forma, a confiança e a euforia em relação ao progresso científico fornece a base para a formulação da sociologia positiva de Auguste Comte (1798-1857) propositor da lei dos três estados, pela qual o desenvolvimento do conhecimento humano havia percorrido três fases distintas: a teológica; a metafísica e a científica - sendo que, apenas na terceira fase, ou seja, com a ciência positivista a humanidade encontrava a maturidade definitiva. Apresentando os fundamentos de uma teorização sociológica característica do modelo "positivo" das ciências naturais e utilizando analogias mecânicas e orgânicas, Comte distingue entre estático (ordem - a causa) e dinâmico (progresso - o efeito), segundo a crença de que a civilização ruma sempre numa direção "positiva" (o ideal do progresso científico-tecnológico), apoiada numa ordem, enquanto lei causal, determinante para a existência social (BAUER, 2009). Dessa feita, ao extrapolar a metodologia das ciências naturais para o estudo da sociedade, Comte inaugura o pensamento positivista que por muito tempo iria predominar quase que absoluto nos estudos sociais.

Contudo, é a Émile Durkheim (1858-1917) que se atribui o mérito de fundador da sociologia acadêmica moderna, que respaldado no positivismo comteano, constrói as bases da sociologia funcionalista que se manteve hegemônica no campo dos estudos sociais até a metade do século passado. Um exemplo claro da transposição da metodologia das ciências naturais para o campo do social é o tratamento dos fatos sociais como "coisas", ou seja, como uma realidade que é dada e que se impõe externamente ao observador. Assim, a própria sociologia deveria, segundo Durkheim (2009), ao analisar o 
fato social, partir de suas dimensões externas, regulares, observáveis e mensuráveis e não de aspectos internos ao indivíduo.

Nesse contexto, a sociedade precede o indivíduo e se sobrepõe a ele, justamente mediante os fatos sociais que, revestido pelas leis, pelas instituições da sociedade e pela educação, tem o papel de conformar o indivíduo a um determinado padrão de comportamento social. Ao indivíduo, cabe se conformar a estes padrões sob pena de ser excluído do sistema.

Contudo, é o conceito de divisão social do trabalho e de coesão social que mais expressa o caráter funcionalista do trabalho de Durkheim. Para ele, a divisão social do trabalho pode ser comparada a um organismo, em que as diferentes funções e especificações são complementares e, portanto, geradoras da integração social, integração esta que ele chama de solidariedade orgânica. Assim, diferentemente das sociedades primitivas, em que a integração social era dada por meio da crença, da língua e das leis e costumes, nas sociedades modernas, esta coesão se daria por meio do trabalho, ou seja, da divisão social do trabalho, único meio, a partir de então, de conformação das relações sociais.

Entretanto, é importante ressaltar que, mesmo antes do positivismo de Comte e Durkheim, é possível constatar a influência positivista na formulação de algumas teorias e conceitos que ainda perduram em nossa sociedade. Para Bauer (2009) dois exemplos podem se destacar: A metáfora da "mão invisível" (natural) de Adam Smith, segundo a qual o comércio e a indústria são guiados por uma lei (também natural) de oferta e demanda, e que se constitui no principal fundamento do liberalismo econômico; e o conceito de "darwinismo social", que extremou o conceito de "mão invisível" numa relação entre a teoria da seleção natural de Darwin e o universo social que, desde Darwin, principalmente por meio da obra de Herbert Spencer, vem sendo utilizada para dirimir a compaixão e esclarecer serem os pobres os inadaptados na seleção natural do capitalismo.

Daí se depreende que a transposição dos preceitos da nova racionalidade para o plano do social não aconteceu de forma despropositada, mas sim porque favorecia a elite dominante, que precisava justificar as desigualdades que começavam a brotar desde 
muito cedo na economia capitalista em plena ascensão. Como descreve Santos (2002, p. 64-65):

\begin{abstract}
O determinismo mecanicista é o horizonte certo de uma forma de conhecimento que se pretende utilitário e funcional, reconhecido menos pela capacidade de compreender profundamente o real do que pela capacidade de $o$ dominar e transformar. No plano social, é esse também o horizonte cognitivo mais adequado aos interesses da burguesia ascendente, que via na sociedade, em que começava a dominar, o estágio final da evolução da humanidade (o estado positivo de Comte, a sociedade industrial de Spencer, a solidariedade orgânica de Durkheim). Daí que o prestígio de Newton e das leis simples a que reduzia toda a complexidade da ordem cósmica tenham convertido a ciência moderna no modelo de racionalidade hegemônica que pouco a pouco transbordou do estudo da natureza para o estudo da sociedade. Tal como foi possível descobrir as leis da natureza, seria possível descobrir as leis da sociedade.
\end{abstract}

Para Campos (1997) este paradigma mecanicista, que deu o tom do progresso científico e tecnológico, que conformou as relações sociais na sociedade moderna e que ainda hoje é dominante, tem como concepção fundamental o universo como sistema mecânico, externo ao indivíduo, formado por partes estanques, ordenado segundo leis estáticas desvendáveis pela ciência, por meio do desenvolvimento de teorias. Para a autora tal concepção suportou a crença na possibilidade de fazê-lo melhor conhecido pela via da subdivisão progressiva das partes, sem prejuízo da essência do todo. 0 reducionismo, a fragmentação e o determinismo, típicos do método científico desta concepção de mundo, desdobraram-se na era moderna na ilusão da neutralidade, na dificuldade de se aceitar e lidar com opostos, no paroquialismo e na arrogância.

A fragmentação progressiva foi deixando suas marcas ao estabelecer a divisão entre mente e corpo, e mais tarde a separação da mente humana em racional e intuitiva. Dado que o próprio método impedia a apreciação entre os opostos, a ciência favoreceu o pensamento racional, em prejuízo do pensamento intuitivo; favoreceu o objetivo em detrimento do subjetivo. Dessa feita, a concepção fragmentada reproduz-se nos modelos organizacionais nos quais se supõe a política separada da administração; o planejamento da execução e a separação entre os que pensam e os que fazem, em que é tributária a epistemologia da administração, preconizada por Fayol e Taylor, e bastante viva ainda hoje. 
O pensamento linear revela-se nas tentativas de aplicar aos problemas divergentes suposições simplistas de causa e efeito; na crença de que tudo se desdobra numa sequência mandatória de fases; na fé cega no progresso, no desenvolvimento, na globalização, traduzida na certeza de que tudo que está por vir será melhor do que o que já passou (SANTOS, 2002). Estas relações simplistas de causa e efeito podem explicar o determinismo com o qual se revestem muitas das abordagens nos estudos sociais e organizacionais: sempre haverá uma "melhor maneira" de resolver um problema, proveniente sempre de uma determinada causa (the one best way de Taylor).

Exemplos claros de reducionismo podem ser percebidos na literatura organizacional, quando se percebe a racionalidade instrumental tomada como a razão humana; a lógica econômica como a lógica da vida; o ser humano reduzido ao recurso humano; o trabalho ao emprego formal na organização econômica; o sucesso no emprego e no cargo como sinônimo de autorrealização; o lucro como principal quando não o único parâmetro de desempenho organizacional; e o crescimento econômico como a única forma de progresso humano (CAMPOS, 1997).

Estas considerações nos remetem à Dialética do Esclarecimento de Adorno e Horkheimer, publicada pela primeira vez em 1947, nos quais tais autores defendem que o esclarecimento que tomou o ocidente no século das luzes converte-se novamente em mito quando, ao colocar todo o conhecimento e toda a ciência a serviço da dominação da natureza, da tecnologia e do capital, acaba por exercer a mesma dominação e controle que as figuras mitológicas outrora exerciam na humanidade, isto porque como representações da essência da realidade e da verdade, as figuras mitológicas e também agora o progresso, o mercado e o capital não deixam nenhuma brecha para a esperança, já que em ambos os casos a realidade é dada como fato acabado (ADORNO; HORKHEIMER, 2011).

\section{A Teoria Geral dos Sistemas nas Ciências Sociais}

Num capítulo de seu livro Gestão da Mudança: Caos e Complexidade nas Organizações, Bauer (2009) apresenta a física quântica como o início do fim do reducionismo, seguido das primeiras descobertas da física quântica, diversas outras teorias que despontaram em meados do século passado tentam demonstrar a 
complexidade dos sistemas, os princípios de incerteza, de indeterminismo e de não linearidade. É nesse contexto que situamos a teoria geral dos sistemas, que, como apregoa este autor, também é fruto da necessidade de se procurar alternativas para o reducionismo até então vigente.

Assim, a teoria geral dos sistemas surge nos estudos sociais e organizacionais com o intuito de sanar o reducionismo e o mecanicismo que permeava o funcionalismo clássico. Como sugere Demo (1989, p. 209), “a metodologia sistêmica esconde atrás de si, entre outros elementos, também certa decepção com o especialista demasiado, que sabe até a idiotice tudo sobre apenas certa coisa". Busca-se então por meio da descoberta de propriedades comuns a todos os sistemas o que o referido autor chama de o "especialista em generalidades", ou seja, o homem capaz de conservar a supervisão do sistema global entravada pelo intento voraz de decomposição analítica.

A teoria dos sistemas, ainda que herdeira do Positivismo inicia uma crítica ao mecanicismo até então incontestável, que divide organismos em agregados de células, células em agregados de moléculas, moléculas em agregados de átomos, e o comportamento humano num agregado de reflexos condicionados e incondicionados (BAUER, 2009, p. 44).

Parece, contudo, haver certa tendência, por parte de alguns autores, de considerar a teoria dos sistemas como um simples desdobramento das teorias funcionalistas, como é o caso de Souza (2001). Defende-se aqui a ideia de que se o funcionalismo está fortemente influenciado pelo conceito de "causalidade social", que liga a teoria social, conceitualmente à física, como é o caso do "fato social" de Durkheim (CAPRA, 2002); e que a compreensão sistêmica baseia-se no pressuposto de que a organização social é análoga aos sistemas vivos, biológicos, apresentando padrões de organização semelhantes a estes sistemas.

[...] biologicamente a vida não é manutenção e restauração do equilíbrio, mas essencialmente manutenção de desequilíbrios, como revela a doutrina do organismo como sistema aberto. Nestes termos assume-se não só o ponto de vista da funcionalidade das partes, mas também, e até certo ponto, sobretudo, a convivência normal com a disfuncionalidade, dentro, porém de um contexto de organização (DEMO, 1989, p. 215) 
Assim, se antes a unificação das ciências tinha sido vista como redução de todas as ciências à física, a resolução final de todos os fenômenos em acontecimentos físicos, do ponto de vista da teoria geral dos sistemas, a unidade da ciência ganha um aspecto mais realista, porque considera a isomorfia das leis em diferentes campos. A função integradora desta teoria se resume na consideração das uniformidades estruturais que se manifestam por traços isomórficos de ordem nos diferentes níveis e domínios (BERTALANFFY, 2008).

Vale ressaltar, entretanto, que essa postura é derivada de sua base positivista, que vê a ciência como um empreendimento nomotético, isto é, que estabelece leis baseadas no fato de os acontecimentos na natureza serem repetitivos e recorrentes, e daí a base para o estudo das relações isomórficas que acabam por torná-la uma teoria que busca entender o mundo como organização, como relação (DEMO, 1989). Originalmente, um sistema é um conjunto de elementos em interação. Mas, inúmeras outras definições mais detalhadas foram elaboradas, tais como: a) um sistema é um todo organizado e complexo; b) sistema é um conjunto de elementos interdependentes, cujo resultado final é superior ao somatório dos resultados que esses elementos teriam caso operassem de forma isolada; e c) sistema é qualquer conjunto de partes reunidas, desde que caracterizado pelas relações entre partes e pelo comportamento do todo (BAUER, 2009). De forma sintética, o sistema dá primazia a duas dimensões importantes: a) um todo inter-relacionado e b) o todo organiza as partes.

No entanto, foi a redescoberta do fenômeno cibernético que superou o conceito exposto acima trazendo para a teoria dos sistemas a noção de dinamismo e autorregulação. Sistema é autorregulação. Por meio dos conceitos advindos da teoria da informação (input, conversão, output, feedback), a cibernética levou à constatação de que o sistema não se atém mais apenas ao fenômeno da inter-relação das partes e de sua organização interna, mas centra-se, sobretudo no discernimento da propriedade da organização autossuficiente, com regulação própria. A capacidade de absorver informação e de responder a ela deu origem ao conceito de realimentação sistêmica, que passou a ser considerada o ponto essencial da definição de sistema, porque é a alma da autorregulação. A retroalimentação do sistema é o que o torna um todo, dá-lhe contorno 
delineável e explica sua razão de persistência, ou seja, que o torna sistêmico (DEMO, 1989).

Assim, o sistemismo se revela bem mais dinâmico do que o funcionalismo e o estruturalismo, com os quais muitas vezes é comparado e até mesmo confundido. Este dinamismo, segundo Demo (1989, p. 217-218), depreende-se, sobretudo, de três conceitos básicos:

a) o conceito de contingência que denota que todo sistema tem organização contingente e, portanto não rígida; b) o conceito de coerções que ao representar o reverso da contingência, implica que a capacidade de coadunação do todo é significada pela coerção - por aquilo que mantém o todo unido, que mantém de maneira homogênea um todo heterogêneo; e c) retoma-se ao primeiro conceito, acrescentando-se apenas o caráter probabilístico de toda a organização. Por mais organizado que seja um sistema, a possibilidade de desorganização não poder ser eliminada, mesmo porque já faz parte da visão dinâmica de sistema.

Tais conceitos permitem, segundo o autor, a colocação tão cara ao sistemismo de "sistema aberto". Assim, o sistema é aberto se não se basta a si mesmo, se não há só dinamismo interno, isolado em si, mas convivência com mundos externos, com o qual convive por vezes, conflituosamente. Não se parte de um equilíbrio funcionalista, mas da sobrevivência em ambiente adverso.

Ao se considerar os conceitos de inputs, outputs, transformação e feedback, entende-se que a estabilidade do sistema é mantida por uma cadeia causal de estímulo/resposta. O conceito de feedback quando utilizado nos sistemas sociais funciona basicamente para diminuir as dissonâncias entre o sistema e o entorno, preservando a estabilidade. É possível, contudo, como ressalta Ribeiro e Neves (2005) a partir da descoberta de sistemas instáveis, caóticos e indeterminados, em que avulta a ideia de que a ordem pode emergir do caos, falar em transformação, embora o novo sistema, tanto quanto o anterior, há de desenvolver procedimentos capazes de superar qualquer ameaça de extinção. Isto porque a teoria do sistema trata da sobrevida da sociedade, da sua reprodução.

Isto posto, ao ressaltar a diversidade e a complexidade dos sistemas, a inter-relação e sinergia que existe entre os seus diferentes elementos e sua interação dinâmica com o ambiente, a abordagem sistêmica adverte para a fragilidade das explicações reducionistas 
e mecanicistas da realidade, que, ao separar a parte do todo, negligenciam as inúmeras inter-relações que existem entre as diferentes partes, e delas com o ambiente. Assim, a abordagem sistêmica aponta para uma reorientação da visão do observador para a diversidade, as inter-relações e os mecanismos de adaptação que ocorrem no sistema e entre ele e o ambiente, o que deveria, conforme observa Souza (2001), conduzir para uma posição de maior humildade do homem perante o mundo, o que de fato quase nunca ocorre.

\section{Crítica ao método sistêmico}

A principal crítica à teoria geral dos sistemas parece ser proveniente de seu biologismo, ou seja, da tentativa de explicar os fatos sociais por meio de conceitos advindos das ciências naturais. Se o funcionalismo parte da matemática e da física para formular suas teorias acerca do universo, o sistemismo parte das ciências biológicas e por isso não supera a tendência que condiciona as ciências sociais à racionalidade das ciências da natureza, em que não se leva em conta o papel da cultura e da intencionalidade emancipada sobre a realidade.

Ao analisar a realidade social e as organizações utilizando-se instrumentos importados da biologia, a TGS pressupõe que o objeto de sua análise tende a tornar-se tão previsível quanto os sistemas biológicos, e por isso constrói uma teorização baseada na predição, no controle e na intenção de manter um equilíbrio constante, o que é incompatível com a natureza complexa das ciências sociais (DEMO, 1989). Assim, a despeito de toda a utilidade que esta teoria teve para a prática organizacional, pode-se inferir dela aspectos bastante perversos quando analisada de um ponto de vista crítico, isto porque, ao ser aplicada na esfera social, com base nos seus pressupostos de controle e regulação, ela cria mecanismos que, a despeito de todos os problemas vigentes na esfera social, buscam manter constantemente a ordem vigente. No contexto particular da análise social e organizacional a epistemologia dominante permanece irredutível.

Afinado com esta crítica, Souza (2001) observa que por enfatizarem tanto os aspectos de integração, organização, funcionalidade, propósito, evolução e interrelacionamento sistêmico, as teorias sistêmicas deixam de fora da análise social toda e qualquer noção de poder, conflito e dominação que permeia toda a organização social. A 
análise sistêmica subtrai a ideia de que uma organização social não é um sistema simétrico, no qual todos têm o mesmo papel na realização dos fins, mas sim um sistema em que existem disputas de poder, e alguns membros, mais do que outros, são os responsáveis pela determinação dos propósitos, e alguns são cooptados e controlados pela organização social. Da mesma forma, o sistemismo, sobretudo a partir da TGS, passa a desconsiderar que cada elemento que participa da organização social é um sujeito político, possui livre arbítrio e pode arcar com as consequências de suas decisões e, portanto, que as relações que permeiam a sociedade de uma maneira geral não podem ser resumidas à condição biológica.

Nesta mesma linha de pensamento, recorremos às opiniões de Demo (1989), que caracteriza as relações de conflito consideradas pela teoria sistêmica como uma "dialética não antagônica", já que, em se partindo da definição de que um sistema é um todo que se autorregula, todo o conflito que ocorre dentro do sistema é, portanto, regulável. $\mathrm{O}$ autor explica que esta noção é derivada da característica metodológica central de circularidade sistêmica que se funda no processo de retroalimentação, que religa output ao input, e que se choca com a dialética porque tende a considerar mudança dentro do sistema mas nunca do sistema.

Isso significa que, mesmo sendo depositária dos méritos de ter avançado neste campo em relação às teorias funcionalistas que consideram o conflito como mera disfunção, a TGS ainda que o admita o percebe como possivelmente domesticável e regulável e, portanto, em nada avança no sentido de conduzir a superações históricas; mas de forma idêntica ao funcionalismo conduz apenas para reformas incrementais, com o intento de manter a ordem e a integração.

Ao discorrer sobre os aspectos relacionais da TGS, Demo (1989) tece críticas ainda mais incisivas ao seu organicismo quando afirma que a concepção científica do mundo tem se apartado do interesse pela substância, pelas qualidades e propriedades inerentes, voltando-se para a focalização central dos princípios da organização em si, dos princípios relacionais, sem levar em conta o que é que está organizado.

Talvez isto constitua até certo ponto o componente terrificante lançado sobre o sistemismo e todas as metodologias que privilegiam o aspecto relacional da realidade, fomentando visão estática e desumana, por prejudicar o tratamento 
de conteúdos históricos. O computador não capta o homem, mas aspectos relacionais que cabem num cartão perfurado de acordo com um código frio. 0 homem reduz-se a feixe de variáveis. No campo relacional, ademais, não entram horizontes éticos, pelo que o homem tende a aparecer como peça perdida na imensa maquinaria da organização social e física (DEMO, 1989, p. 213).

Ainda nos termos deste autor, ao aplicar o modelo cibernético à política, a teoria sistêmica torna-se bastante conveniente aos olhos dos que dominam a cena do poder. A capacidade de desenvolver expedientes de controle social por meio da coleta e sofisticação de dados, previsão de conflitos, manejo de riscos políticos e etc., torna as ciências sociais um instrumento formidável de domesticação das massas.

Para Morin (2005a), a cibernética ao mesmo tempo em que enriquece as ciências sociais, restaurando o principio de totalidade complexa, transpõe por meio de sua base paradigmática e epistemológica o princípio de racionalidade e funcionalidade para o campo social e reduz tudo aquilo que é social, humano e biológico à lógica unidimensional das máquinas artificiais.

Corroborando estas colocações, Bauer (2009) afirma que a principal deficiência que se constata hoje na teoria dos sistemas é justamente a noção de equilíbrio, que esta teoria forjou dos sistemas naturais, em que o ciclo ininterrupto de funcionamento de um sistema cibernético tem como produto último justamente o equilíbrio. Ao contrário do que se costumava acreditar, na natureza, as situações de equilíbrio são antes exceção do que regra, e isso tem sido comprovado com a descoberta dos sistemas complexos. Com a descoberta da não linearidade, as teorias do caos apelam a suspeitar da capacidade de ação (controle das causas) e a capacidade de previsão (controle das consequências), pondo em causa a ideia de transparência entre causa e efeito e, portanto, de equilíbrio constante (SANTOS, 2002). Da mesma forma, nos tempos atuais, atributos como permanência, estabilidade e equilíbrio são os que menos existem nas esferas sociais, econômicas, culturais, políticas etc.

Nestes termos, dentro da perspectiva sistêmica não é possível conceber uma mudança significativa nos pressupostos epistemológicos que conformam a teoria e a prática organizacional no sentido de se transpor a racionalidade instrumental e substituí- 
la por uma racionalidade mais substantiva, ${ }^{1}$ em que aspectos humanos, sociais, ambientais e valorativos passem a ser também considerados no contexto organizacional, que ainda hoje dá primazia total à eficiência, ao lucro e ao crescimento contínuo. Haja vista sua limitação em romper com os pressupostos de controle e regulação do paradigma hegemônico.

\section{Uma reformulação do conceito de sistemas proposto pela Teoria da}

\section{Complexidade}

Em sua obra, Ciência com Consciência, Morin (2005a) afirma que a teoria dos sistemas resolveu aparentemente o problema do reducionismo ao incorporar o holismo como novo princípio; aqui busca-se a explicação no nível da totalidade ao invés da explicação no nível dos elementos de base como fazia o reducionismo. Contudo, para o autor, o holismo proposto pela teoria dos sistemas depende do mesmo princípio simplificador que o reducionismo ao qual se opõe (ideia simplificada do todo e redução do todo), só abrangendo visão parcial, unidimensional e simplificadora do todo.

O autor propõe então uma reconceituação de sistemas e preconiza que um sistema precisa passar a ser visto como sendo, a um só tempo, tanto mais como menos que a soma de suas partes. Mais porque a reunião das partes permite o surgimento de novas potencialidades para o conjunto, qualidades emergentes que também retroalimentam as partes, estimulando-as a expressar suas potencialidades individuais, e menos porque o conjunto acaba por determinar restrições às partes e as inibe de expressar aquelas mesmas potencialidades individuais. "O homem, por exemplo, associado a outros homens, é integrante de uma sociedade produtora de cultura, que ao mesmo tempo o estimula e o constrange" (BAUER, 2009, p. 51). Essa definição de sistema inaugura uma nova concepção de mundo e de realidade, apontando para um dinamismo organizacional bastante contrário ao determinismo concebido pela ciência clássica.

Nesse sentido, o que Morin (2005a) propõe é, sobretudo, o reconhecimento da circularidade nas explicações simultâneas do todo pelas partes e das partes pelo todo, ou

\footnotetext{
${ }^{1}$ Ver Ramos (1981). A Razão Instrumental é baseada no cálculo das consequências utilitárias de cada ato humano. A Razão Substantiva orienta o homem na ordenação de sua vida pessoal e social eticamente em direção à autorrealização.
} 
seja, ambas essas explicações são complementares, sem que nenhuma possa anular as características antagônicas e concorrentes da outra. Três circularidades são propostas pelo autor, que constrói uma visão complexa da realidade: a circularidade todo - partes; a circularidade unidade - diversidade; e a circularidade ordem - desordem.

No que se refere à primeira circularidade, "a visão simplificada diria: a parte está no todo. A visão complexa diz: não só a parte está no todo; o todo está no interior da parte que está no interior do todo!" (MORIN, 2007, p. 88). Isso é verdade para cada célula do nosso organismo que contém a totalidade do código genético presente em nosso corpo. Isso é verdade também para a sociedade que desde nossa infância se imprime como todo em nossa mente, por meio da linguagem, da cultura, das crenças e saberes. 0 indivíduo está na sociedade, que está no indivíduo. Daí surge o princípio hologramático, que juntamente com os princípios recursivo e dialógico são utilizados por Edgar Morin para explicar a trindade indivíduo/sociedade/espécie, ou seja, a relação entre estas três instâncias que compõe a totalidade.

A circularidade unidade-diversidade implica que o todo existe enquanto uma única unidade global, mas as partes têm dupla identidade, preservando suas identidades próprias, não redutíveis ao todo e também constituindo uma identidade comum. Assim, ao mesmo tempo em que a diversidade constrói a unidade, a unidade constrói a diversidade. A relação sociedade - indivíduo, de acordo com o princípio recursivo, não se realiza por um determinismo social que tolera margens de autonomia individual, mas mediante um anel de produção mútua entre indivíduos e sociedade, no qual a sociedade é produzida pelas interações entre indivíduos, mas, uma vez produzida, retroage sobre os indivíduos e os produz. Assim, os indivíduos produzem a sociedade que produz os indivíduos. "A emergência social depende da organização mental dos indivíduos, mas a emergência mental depende da organização social" (MORIN, 2005b, p. 167).

Contudo, como bem ressalta Bauer (2009), a principal das circularidades, proposta por Morin e a que exprime a essência do sentido de complexidade, dá-se entre as instâncias da ordem e da desordem: circularidade ordem - desordem. "O que digo a respeito da ordem e da desordem pode ser concebido em termos dialógicos" (MORIN, 2007, p. 74). Entre indivíduos e sociedade, que se complementam, também existem antagonismos, que vêm da oposição entre egocentrismo e sociocentrismo; a sociedade 
reprime pulsões, desejos e aspirações individuais; essas pulsões, desejos e aspirações tendem a transgredir as barreiras, normas e interdições da sociedade, colocadas justamente para inibi-los e recalcá-los. A ordem e a desordem são dois inimigos: um suprime o outro, mas ao mesmo tempo, em certos casos, eles colaboram e produzem organização e complexidade. O princípio dialógico, desta forma, permite mesmo no seio da unidade (sociedade) manter a dualidade (diversidade individual). Ele associa dois termos ao mesmo tempo complementares e antagônicos.

Nesta reelaboração do conceito de sistemas, proposta por Morin (2005a), alguns conceitos clássicos são superados: a) o reducionismo, que busca compreender o todo com base nas descrições das partes; b) o holismo, que em sua vertente totalizante é também simplificador já que reduz o que é por natureza complexo a uma única instância-chave (o todo), terminando por negligenciar as partes; e c) o hierarquismo, que impõe uma precedência unilateral do todo sobre as partes, por meio de sistemas que englobem sistemas que englobem sistemas etc. A evolução rumo ao paradigma da complexidade deve passar a considerar a circularidade e a recorrência de instâncias que são entre si complementares, concorrentes e antagônicas. De uma relação linear de causa-efeito determinista, passa-se a considerar relações recíprocas que condizem com a autoorganização e o dinamismo do sistema.

Daí a definição que Morin (2007, p. 13) traz da complexidade: "a complexidade é um tecido (complexus: o que é tecido junto) de constituintes heterogêneas inseparavelmente associadas: ela coloca o paradoxo do uno e do múltiplo". Complexidade é efetivamente o tecido de acontecimentos, ações, interações, retroações, determinações e acasos que constitui o universo fenomênico.

Ao reformular o conceito de sistemas, Morin (2005a) antecede seu pensamento complexo. Dessa feita, dentro de sua visão complexa o ser humano é parte do que o autor denomina trindade "indivíduo/sociedade/espécie" que de forma hologramática, recursiva e dialógica funcionam numa engrenagem de dependência recíproca, umas gerando as outras. Assim, a própria reprodução da espécie é ela mesma influenciada pela sociedade que por meio de sua cultura estabelece as regras da vida em comum. "A sociedade se autoproduz pela reprodução biológica, que se auto-reproduz de acordo com a norma sociológica." (MORIN, 2005b, p. 170). 
Dessa forma, contrariando a ciência tradicional em que tudo é determinismo, a complexidade de Morin traz à tona a emergência do sujeito e, consequentemente, da autonomia. Mundo e sujeito são colocados em situação de reciprocidade e inseparabilidade, contudo, dada esta inseparabilidade, a própria autonomia é ela mesma dependente. Surge então o conceito de autonomia dependente: não há sociedade sem indivíduos e não há indivíduos propriamente humanos dotados de espírito, linguagem e cultura sem sociedade. Ao mesmo tempo em que o indivíduo recebe influências do seu meio cultural, também é dotado de autonomia inata, que inibe o total determinismo cultural e social.

Então, ser sujeito é ser autônomo, sendo ao mesmo tempo dependente. Dependente de seu patrimônio genético, do qual depende sua autonomia cerebral; de seu meio ecológico, do qual depende sua autonomia biológica; das normas sociais, no qual, por meio da cultura, adquire seu modo individual de conhecer, de comportar-se e adquire sua autonomia mental (MORIN, 2005b). Portanto, a autonomia alimenta-se de dependências; para ser quem somos dependemos de uma sociedade, de uma cultura, da linguagem, de educação, mas também de nossos genes, estes últimos, nos permitem ter um cérebro e uma mente e de poder assumir uma cultura e exercer autonomia sobre o meio em que vivemos.

Para Morin, uma vez que a natureza humana é complexa, da mesma forma ela deve ser vivenciada, e por isso a sociedade que mais favorece as autonomias individuais é a sociedade complexa. "A alta complexidade está ligada ao desenvolvimento das comunicações, das trocas econômicas e de idéias, ao jogo dos antagonismos entre interesses, paixões e opiniões" (MORIN, 2005b, p. 274). Quanto maior os pluralismos no campo econômico, político e cultural, maior são as possibilidades de liberdade e escolha individual e menos nossa vida é programada em relação aos genes, à sociedade e à cultura. Para o autor, é nestas condições que a submissão do indivíduo se torna moderada, que a marca indelével dos determinismos culturais passam a conformar algumas brechas, e que os desvios passam a desempenhar um papel inovador ao invés de serem rechaçados. A complexidade social limita a exploração e a subjugação do indivíduo ao aparelho do Estado e das normas sociais, permitindo autonomia física, mental e espiritual. 
Dessa forma, ao conceber o indivíduo autônomo e capaz de influir no processo social, a teoria da complexidade, assim como a dialética, afasta-se da concepção metafísica hegemônica, da qual é tributário o funcionalismo e o sistemismo e que, como salienta Konder (1998, p. 9), "prevaleceu ao longo do tempo porque correspondia, nas sociedades divididas em classes, aos interesses das classes dominantes, sempre preocupadas em organizar duradouramente o que já estava funcionando". Contudo, uma análise mais profunda da metodologia complexa aponta para um novo conceito de transformação, se é que se pode falar assim, que, ao contrário da dialética, não prevê necessariamente a transformação com base na superação de um modelo social pelo outro, mas, sim, a possibilidade de convivência de diversas formas diferentes de organização social no seio de uma mesma sociedade complexa.

A complexidade apresentada por Morin propõe uma nova lógica que se opõe à visão polarizada e excludente entre princípios organizativos distintos, defendendo em seu lugar a necessidade de modelos híbridos e complementares, considerando-se que a realidade é multifacetada, constituída por uma infinidade de nuances que não podem ser reduzidas ou aniquiladas, mas respeitadas como inerentes à realidade social em que vivemos. Todavia essa posição tão genuína à teoria da complexidade encontra críticas em distintos autores, como Harvey (2005) que entende essa posição como uma forma de relativismo, que tenta acomodar forças e propostas distintas quando não contrárias, o que tende a conduzir a um processo de cooptação, pertencendo ao plano imaginário a possibilidade de convivência pacífica entre interesses declaradamente opostos.

Santos (2007) traz alguns avanços ao afirmar que a teoria crítica centra-se na defesa do princípio da igualdade, mas foi incapaz de reconhecer as diferenças, o que se opõe à própria realidade. Nesse sentido, o autor vê na teoria da complexidade uma outra maneira de entender o mundo em termos políticos e epistemológicos, não numa aderência ao relativismo, mas antes numa convivência entre movimentos que, mesmo distintos, comungam em pontos fundamentais, nomeadamente nos ideais emancipatórios e na defesa de propostas contra-hegemônicas, o que poderá sinalizar avanços importantes.

\section{Complexidade e Dialética}


Para melhor elucidarmos as afirmações anteriores, partiremos de uma comparação entre aspectos fundamentais da relação sociedade-indivíduo do ponto de vista da complexidade com a dialética histórico-estrutural marxista. Ambas parecem concordar que o indivíduo pode influir na transformação social, porém, se para a dialética marxista o ator político está condicionado pela estrutura objetiva da sociedade, ou seja, pelas condições econômicas que se lhes impõe, para a complexidade ele é muito menos dependente destas sanções, ou melhor, tanto menos dependente quanto maior for sua participação na vida cultural, política e ideológica da sociedade, já que é nestes aspectos da vida em sociedade que reside a formação da consciência crítica.

A dialética marxista subordina a vida intelectual à determinação material e por conseguinte, a superestrutura (sistema jurídico, político, artístico, filosófico e ideológico) à infraestrutura (produção econômica material). Estando a condição econômica como determinante de todo o resto, só poderá haver mudança profunda com a superação do modelo econômico, neste caso, superação do modo de produção capitalista por outro. "Dificilmente se poderia admitir revolução na superestrutura, do tipo revolução na educação, na cultura, na arte, na consciência, e mesmo na política" (DEMO, 1989, p. 111), uma vez que a própria consciência, é ela mesma determinada pelo modo de produção.

Neste sentido, enquanto para a dialética marxista a transformação representa, preliminarmente, transformação na forma de produção econômica, da qual deriva todos os aspectos subjetivos da sociedade, para o paradigma da complexidade a transformação se faz possível a partir do próprio indivíduo, que por meio da educação, da arte, da cultura, da política e da participação numa sociedade livre pode desenvolver uma consciência crítica capaz de questionar as bases da sociedade e, portanto, transformá-la (MORIN, 2005b).

Deve-se, no entanto, antes de exaurir está análise levar em conta que enquanto na dialética marxista o objeto de estudo foram as relações capitalistas e as contradições inerentes a esta forma de produção, já que, desde Hegel, a superação dialética se dá por meio do trabalho (KONDER, 1998); para a complexidade, o objeto de estudo é a complexidade social, a complexidade do sujeito e as relações que brotam entre estas duas instâncias. O capitalismo do ponto de vista da teoria da complexidade é apenas uma forma de produção econômica que subordinou toda uma sociedade aos seus ditames e, 
por isso mesmo, reduziu toda a complexidade do sujeito e da vida a um único aspecto - a dimensão econômica. Contudo, dentro de uma abordagem complexa, o que se busca não é a superação deste modelo por outro, mas, sim, a possibilidade da convivência entre o capitalismo e modelos alternativos.

Esta se constitui, inclusive, na principal crítica que a complexidade defere à modernidade - a redução da vida social a um único elemento determinante sobre todos os demais (o econômico); a um único modelo econômico sobre todos os demais (o capitalista); a uma única racionalidade sobre todas as demais (a científica), e assim por diante (MORIN, 2007).

O paradigma da complexidade, dentro da proposta de Edgar Morin, inaugura uma nova forma de conceber o mundo e a sociedade, em que não há espaços para determinismos, hierarquismos e reducionismos. Assim, não se pode conceber determinismos sociais, como se toda a vida fosse determinada por algum fator social que preponderasse sobre os outros; não se pode conceber que uma instância da vida do indivíduo seja mais importante ou se sobreponha a outra e, principalmente, não se pode reduzir a vida humana ao fator econômico, ao trabalho ou ao consumo, como presenciamos em nosso dias. Dessa feita, a própria dialética, na forma como compreendemos aqui, remete à racionalidade criticada pelo paradigma da complexidade uma vez que supõe a revolução apenas por via do fator econômico, sobrepondo-o a todo o resto.

Assim, o paradigma da complexidade rompe com várias posturas da modernidade, principalmente no que se refere à busca de certezas e de uma verdade absoluta, como o fez a dialética marxista ao propor o modelo socialista como ideal. No entanto, para nossas mentes acostumadas a verdades e soluções definitivas, a proposta da complexidade pode, num primeiro momento, parecer um tanto relativista, uma vez que não parte de nenhuma ideia de "estado final das coisas", ou mesmo de uma proposta concreta e de fácil apreensão para superar as mazelas da sociedade contemporânea, como propunha a dialética marxista. 


\section{Considerações finais}

No que se refere às propostas alternativas ao paradigma dominante, entende-se aqui que a teoria sistêmica dá sua contribuição e supera o reducionismo clássico, quando partindo do conceito de sistemas abertos, ressalta a diversidade e a complexidade dos sistemas, a inter-relação e sinergia que existe entre os seus diferentes elementos e sua interação dinâmica com o ambiente. Contudo, infere-se que, por acreditar na possibilidade de um equilíbrio constante e, portanto, na possibilidade de regulação permanente, essa abordagem não se constitui numa alternativa profícua ao pensamento dominante.

O pensamento complexo de Morin, ao enaltecer a independência da parte perante o todo, do indivíduo perante a sociedade e de outras circularidades que compõe a constituição do universo e da vida apresenta um dinamismo maior no entendimento da sociedade e, portanto, parece constituir-se numa alternativa mais concreta ao determinismo e a estabilidade defendidos pela abordagem funcionalista. Parafraseando Serva, Dias e Alperstedt (2010), apontamos para a possibilidade de uma epistemologia da complexidade dar conta dos pontos cegos do paradigma dominante, trazendo uma proposta de transformação no modo de conceber a sociedade, uma proposta que inclua na análise dos sistemas sociais e organizacionais o conflito, as ambiguidades e os paradoxos, por meio de uma lógica também paradoxal.

Do paralelo estabelecido entre teoria da complexidade e dialética marxista, apontou-se para um novo conceito de transformação, se é que se pode falar assim, que, ao contrário da dialética, com a qual parece dialogar em diversos aspectos, não prevê necessariamente a transformação com base na superação de um modelo social pelo outro, mas sim a possibilidade de convivência de diversas formas diferentes de organização social no seio de uma mesma sociedade complexa.

Assim, se por um lado a epistemologia complexa parece ser bastante eficaz ao demonstrar os pontos cegos do paradigma dominante, demonstra certo relativismo quando defende a convivência entre forças distintas, o que nem sempre é fácil de conciliar e pode conduzir a um processo de cooptação em que alguns interesses particulares se sobrepõem e anulam os demais num processo assimétrico de forças interagentes. De acordo com Bauman (2003), a fragmentação excessiva dos interesses 
pode incorrer num processo de individualização, no enfraquecimento do sentido de comunidade e no arrefecimento da luta por uma sociedade economicamente mais justa e socialmente mais consistente, pautada na construção do bem-comum.

Contudo, ainda que a fragmentação e a pluralidade de bandeiras que caracterizam o nosso momento histórico possam fragilizar ou mesmo dificultar a construção de projetos mais profundos e ambiciosos de transformação social, como se acreditava no passado, parece que esta multiplicidade de expressões se sintoniza melhor com as demandas e necessidades particulares de cada grupo social dentro da contemporaneidade. Como alerta Santos (2007), essa variabilidade de propósitos não exclui a existência de pontos de intercepção e convergência, principalmente quando se identificam obstáculos comuns que impedem os avanços de diferentes movimentos sociais, emergindo a necessidade de congregar forças, hoje dispersas, em torno de um projeto contra-hegemônico comum, capaz de promover a emancipação social e a construção do bem-comum sem negligenciar as particularidades inerentes a cada grupo específico.

Assim, sem intencionar qualquer desfecho sobre o assunto, este ensaio buscou auxiliar na compreensão de como o paradigma da complexidade pode se constituir numa alternativa profícua ao entendimento da complexa realidade social contemporânea, quando, diferentemente do paradigma dominante e de outras perspectivas críticas, como a dialética, com a qual a comparamos neste trabalho, defende a necessidade de modelos híbridos e complementares, uma vez que considera a realidade multifacetada e constituída por uma infinidade de nuances que não podem ser reduzidas ou aniquiladas, mas respeitadas como inerentes à realidade social em que vivemos.

\section{Referências}

ADORNO, T. W.; HORKHEIMER, M. Dialética do esclarecimento. Rio de Janeiro: Jorge Zahar, 2011.

ANDERY, M. A. et al. Para compreender a ciência: uma perspectiva histórica. Rio de Janeiro: Garamound, 2007.

BACON, F.; CIVITA, V. Novum organum ou verdadeiras indicações acerca da interpretação da natureza: Nova Atlântida. São Paulo: Nova Cultural, 1999. 
BAETA NEVES, C. E.; NEVES, F. M. O que há de complexo no mundo complexo? Niklas Luhmann e a Teoria dos Sistemas Sociais. Sociologias, Porto Alegre, ano 8, n. 15, p. 182207, jan./jun. 2006.

BAUER, R. Gestão da mudança: caos e complexidade nas organizações. São Paulo: Atlas, 2009.

BAUMAN, Z. Comunidade: a busca por segurança no mundo atual. Rio de Janeiro: Jorge Zahar, 2003.

BERTALANFFY, L. V. Teoria geral dos sistemas. 3. ed. Petrópolis: Vozes, 2008.

CAPRA, F. As conexões ocultas: ciência para uma vida sustentável. São Paulo: Cultrix, 2002.

CAMPOS, A. M. Contribuição para o resgate da relevância do conhecimento para a administração. Physis: Revista de Saúde Coletiva, Rio de Janeiro, v. 7, n. 2, p. 105-127, 1997.

DEMO, P. Metodologia científica em ciências sociais. 2. ed. São Paulo: Atlas, 1989.

DURKHEIM, É. As regras do método sociológico. 3. ed. São Paulo: Martins Fontes, 2009.

HARVEY, D. Condição pós-moderna: uma pesquisa sobre as origens da mudança cultural. 14. ed. São Paulo: Loyola, 2005.

KONDER, L. O que é dialética. 28. ed. São Paulo: Brasilense, 1998.

KUHN, T. S. A estrutura das revoluções científicas. 9. ed. São Paulo: Perspectiva, 2005.

MORIN, E. Ciência com consciência. 8. ed. Rio de Janeiro: Bertrand Brasil, 2005a.

. O método 5: a humanidade da humanidade. 3. ed. Porto Alegre: Sulina, 2005b. Introdução ao pensamento complexo. 3. ed. Porto Alegre: Sulina, 2007.

MORIN, E.; LE MOIGNE, J. L. A inteligência da complexidade. São Paulo: Peirópolis, 2000.

RAMOS, A. G. A nova ciência das organizações. Rio de Janeiro: FGV, 1981.

RIBEIRO, A. M. M.; NEVES, F. M. A conformação dos grupos de pesquisa biotecnologia da cana de açúcar na região norte-fluminence: a perspectiva do "novo sistemismo". Ciências Sociais Unisinos, São Leopoldo, v. 41, n. 3, p. 171-182, set./dez. 2005.

SANTOS, B. S. A crítica da razão indolente, para um novo senso comum. 4. ed. São Paulo: Cortez, 2002.

SANTOS, B. S. Renovar a teoria crítica a reinventar a emancipação social. São Paulo: Boitempo, 2007. 
SERVA, M.; DIAS, T.; ALPERSTEDT, G. D. Paradigma da complexidade e teoria das organizações: uma reflexão epistemológica. RAE, São Paulo, v. 50, n. 3, p. 276-287, 2010.

SOUZA, R. S. O funcionalismo sistêmico nas teorias social e organizacional: evolução e crítica. REAd, Porto Alegre, v. 7, n. 1, jan./fev. 2001. 